Original Research Article

\title{
Histomorphologic spectrum of ovarian cystic lesions at a tertiary care centre
}

\author{
Kanasagara A. ${ }^{1}$, Sarvaiya A. ${ }^{2}$, Sakariya D. ${ }^{3}$ \\ ${ }^{1}$ Dr.Anand Kanasagara, Tutor, ${ }^{2}$ Dr. Ankur Sarvaiya, Assistant Professor, GMERS Medical College, Himmat Nagar, \\ ${ }^{3}$ Dr. Dhaval Sakariya, Pathologist, Surat, Gujarat, India.
}

Corresponding Author: Dr. Ankur Sarvaiya, Assistant Professor, GMERS Medical College, Himmat Nagar. E-mail: ankur.sarvaiya@gmail.com

\begin{abstract}
Introduction: An ovarian cyst is a liquid or semi-liquid material filled sac in an ovary. Proper management depends on the histomorphological division of non neoplastic \& benign and malignant neoplastic lesions. So this study was done to differentiate the lesion histomorphologically and to know the commonest lesion in each age group. Objectives: To study age wise incidence, nonneoplastic, benign and malignant spectrum of ovarian cystic lesions. Methods: A retrospective histo-pathological study of 100 cases of nonneoplastic and neoplastic cystic lesions of ovary was conducted. Result: We found that out of 100 cases, $58 \%$ were non neoplastic and $42 \%$ were neoplastic. Benign cystic teratoma was the most common neoplastic condition. Follicular cyst was the commonest nonneoplastic condition. Conclusion: Histomorphological parameters along with advanced newer diagnostic modalities like immunohistochemistry can help to do early diagnosis and plan the line of treatment $\&$ they have effect on prognostic significance.
\end{abstract}

Key words: Ovarian cyst, Non neoplastic, Neoplastic, cystic lesion of ovary, Follicular cyst

\section{Introduction}

The ovaries are paired pelvic organs located on the sides of the uterus close to the lateral pelvic wall, behind the broad ligament and anterior to the rectum [1]. An ovarian cyst is a liquid or semi-liquid material filled sac in an ovary. Ovarian cyst is a finding of considerable anxiety to women because of the fear of malignancy, but the vast majority are benign. These cysts can develop in females at any stage of life, from the neonatal period to post menopause.

Generally speaking, these tumors are rarer in childhood and adolescent age groups as studies have confirmed that only about $2 \%$ of ovarian tumors are seen in children [2,3]. Most benign lesions of the ovary occur in childbearing age group and are often cystic, while malignant tumors are more common in the elderly women [4]. Globally, ovarian malignancy constitutes about $23 \%$ of all gynecological tumors and $6^{\text {th }}$ most common female cancer with the highest fatality rate $[5,6,7]$. In developing countries including India, there are low epidemiological statistics of ovarian cancers because most cases are underreported, in spite of the fact that it constitutes one of the most common

Manuscript received: $4^{\text {th }}$ July 2018

Reviewed: $14^{\text {th }}$ July 2018

Author Corrected: $20^{\text {th }}$ July 2018

Accepted for Publication: 26 ${ }^{\text {th }}$ July 2018 gynecological problems locally and globally. Ovarian neoplasms are usually detected at a late stage and are large in size, because of their presentation with mild symptoms [8]. Proper management depends on the histomorphological division of nonneoplastic, benign and malignant lesion. So this study was done to differentiate the lesion histomorphologically and to know the commonest lesion in each age group and compare our study to other researches worldwide.

\section{Aims \& Objectives}

1. To obtain age wise incidence of ovarian cystic lesions.

2. To get incidence ratio of non neoplastic versus neoplastic ovarian cystic lesions.

3. To get incidence ratio of benign versus malignant ovarian cystic lesions.

4. To study the morphological aspects of ovarian cystic lesions.

\section{Materials and Methods}

Place of Study: Department of Pathology, N.H.L. Municipal Medical College, Vadilal Sarabhai General Hospital, Ahmedabad. 


\section{Original Research Article}

Type of Study: A retrospective histo-pathological study of 100 cases of nonneoplastic and neoplastic cystic lesions of ovary from December 2013 - October 2015.

Sampling methods \& sample collection: Ovarian specimen was obtained from hysterectomy specimen with unilateral or bilateral adnexa \& oophorectomy and/or cystectomy specimens received in the department.

Tissues were fixed and preserved in formalin, then passed through ascending grades of alcohol and xylene and finally embedded in melted paraffin wax. Then blocks were prepared, single block was made for each section, thin sections of 4 to 5 microns thickness were cut, slides were prepared and stained by hematoxylin \& eosin.

Inclusion Criteria: Only the ovarian specimens having cyst were included in this study.

Exclusion criteria: Ovarian lesions without cyst were excluded from the study.

Statistical Methods: The non-neoplastic and neoplastic cystic lesions from representative sections were studied and classified according to Modified World Health Organisation (WHO) classification 2003 and staging was done according to International Federation of Gynaecology and Obstetrics (FIGO) staging.

\section{Results and Observation}

In a retrospective study of ovarian cystic lesions, we found that out of 100 cases, $58 \%$ were non neoplastic and $42 \%$ were neoplastic. Among the neoplastic ovarian lesions (42 cases), 36 (86\%) cases were benign, 4 (9.5\%) cases were borderline and $2(4.5 \%)$ were malignant. Out of 36 benign ovarian neoplasms, most common histology was benign cystic teratoma followed by mucinous cystadenoma and serous cystadenoma. Total 4 tumours were showing borderline histology, among them 2 were papillary serous, 1 was mucinous and 1 was clear cell carcinoma. We found 2 cases showing malignant histology, both of which were adult granulosa cell tumour type.

Most of the benign neoplastic tumours were observed in the age group of 20-40yr, while most of the malignant tumours cases were common in elderly ( $>40$ years) age group. Among the non-neoplastic lesions (58 cases), we found follicular cysts (27 cases), corpus luteal cysts (26 cases) and endometriotic cysts (5 cases). There were total 14 cases in 21-30 years, 17 cases in 31-40yrs, 23 cases in $>40$ years and 4 cases in $<20$ years of age group among all cystic non-neoplastic lesions (58 cases). So, cystic non neoplastic lesions occur commonly between 20-40 years of age.

Table-1: Age wise Incidence of ovarian cystic lesions.

\begin{tabular}{|c|c|c|c|}
\hline Age (in years) & Non-neoplastic & Neoplastic & Total No. of cases \\
\hline $0-10$ & 2 & 1 & 3 \\
\hline $11-20$ & 2 & 2 & 4 \\
\hline $21-30$ & 14 & 14 & 28 \\
\hline $31-40$ & 17 & 14 & 31 \\
\hline $41-50$ & 21 & 5 & 26 \\
\hline $51-60$ & 2 & 6 & 8 \\
\hline $61-70$ & 0 & 0 & 0 \\
\hline $71-80$ & 0 & 0 & 0 \\
\hline Total & 58 & 42 & 100 \\
\hline
\end{tabular}

Table-2: Age wise distribution of neoplastic cystic lesions.

\begin{tabular}{|c|c|c|c|}
\hline \multicolumn{3}{|c|}{ Neoplastic Lesions } \\
\hline Age & Benign & Borderline & Malignant \\
\hline $0-10$ & 1 & 0 & 0 \\
\hline $11-20$ & 2 & 0 & 0 \\
\hline $21-30$ & 14 & 0 & 0 \\
\hline $31-40$ & 12 & 2 & 1 \\
\hline $41-50$ & 4 & 0 & 1 \\
\hline $51-60$ & 3 & 2 & 0 \\
\hline$>60$ Yrs & 0 & 0 & 2 \\
\hline Total & 36 & 4 & 0 \\
\hline
\end{tabular}




\section{Original Research Article}

Table-3: Histopathological diagnosis of ovarian cystic lesions.

\begin{tabular}{|c|c|}
\hline Lesions & No. of cases \\
\hline Follicular Cyst & 27 \\
\hline Corpus Luteal Cyst & 26 \\
\hline Endometriotic Cyst & 5 \\
\hline Dermoid Cyst & 14 \\
\hline Serous Cystadenoma & 10 \\
\hline Mucinous Cystadenoma & 4 \\
\hline Borderline Tumour & 2 \\
\hline Malignant Tumour & $\mathbf{1 0 0}$ \\
\hline Total & 12 \\
\hline
\end{tabular}

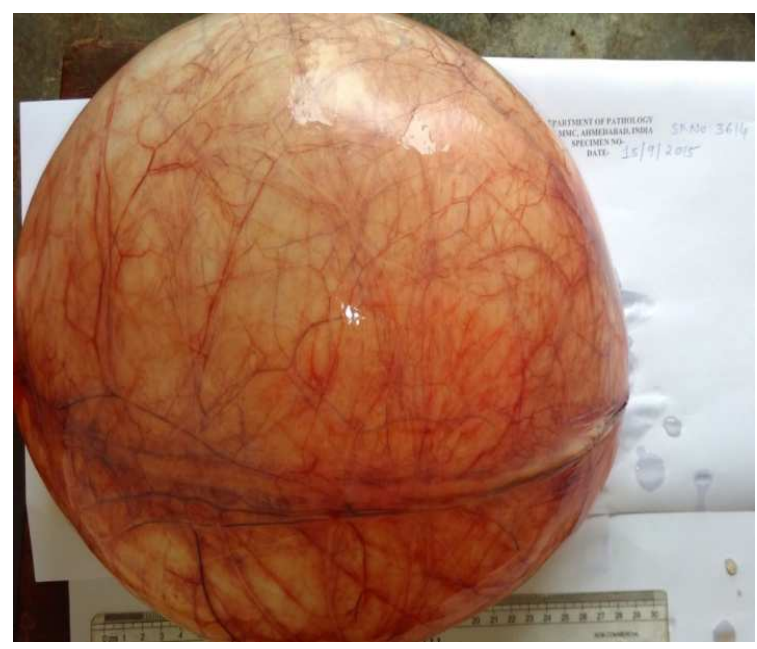

Figure-1: Serous Cystadenoma (Gross)
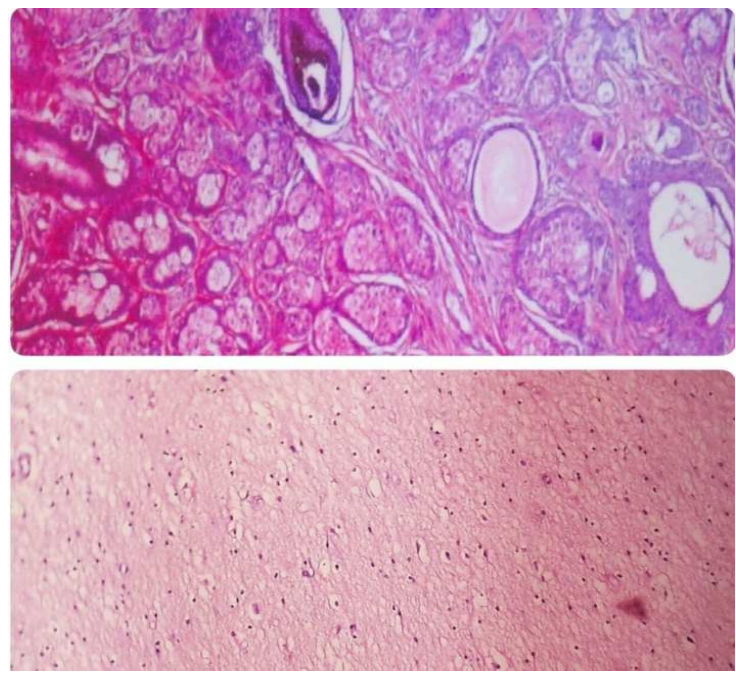

Figure-3: Dermoid Cyst [skin adnexa and adipose tissue (above) glial component (below)]

(10 \& 40x, H \& E stain)
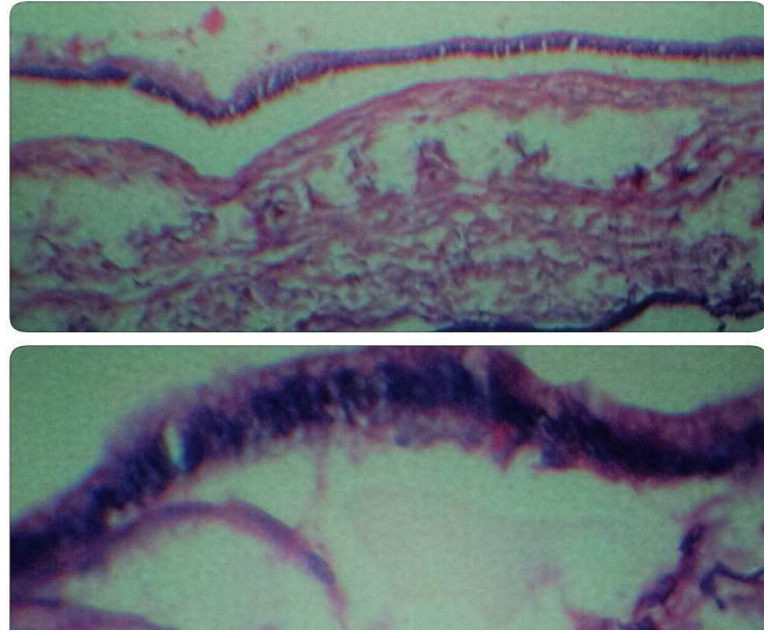

Figure-2: Mucinous Cystadenoma- Cyst lined by tall, non-cilliated columnar cells with basally located nuclei and abundant mucin. (10x, 40x, H \& E stain)
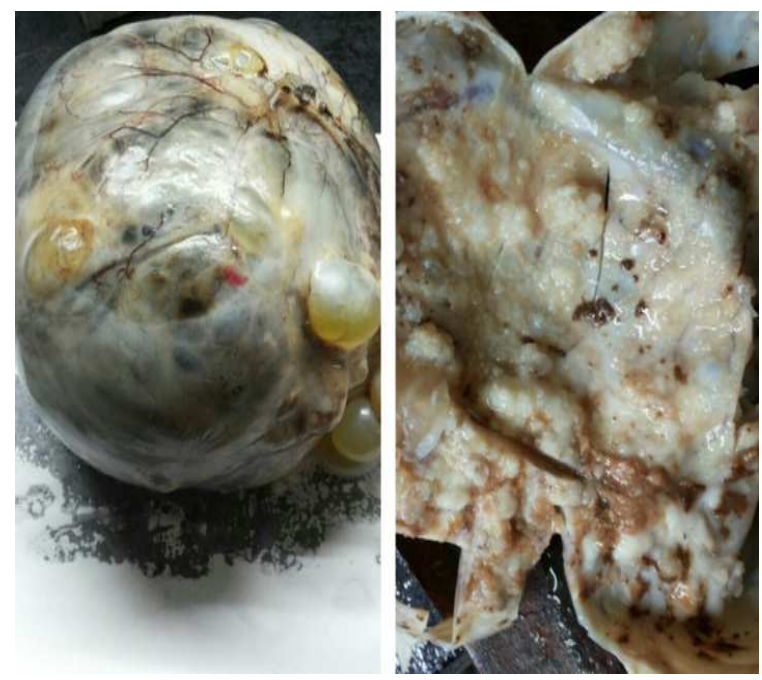

Figure-4: Papillary serous borderline tumour (Gross) 


\section{Original Research Article}
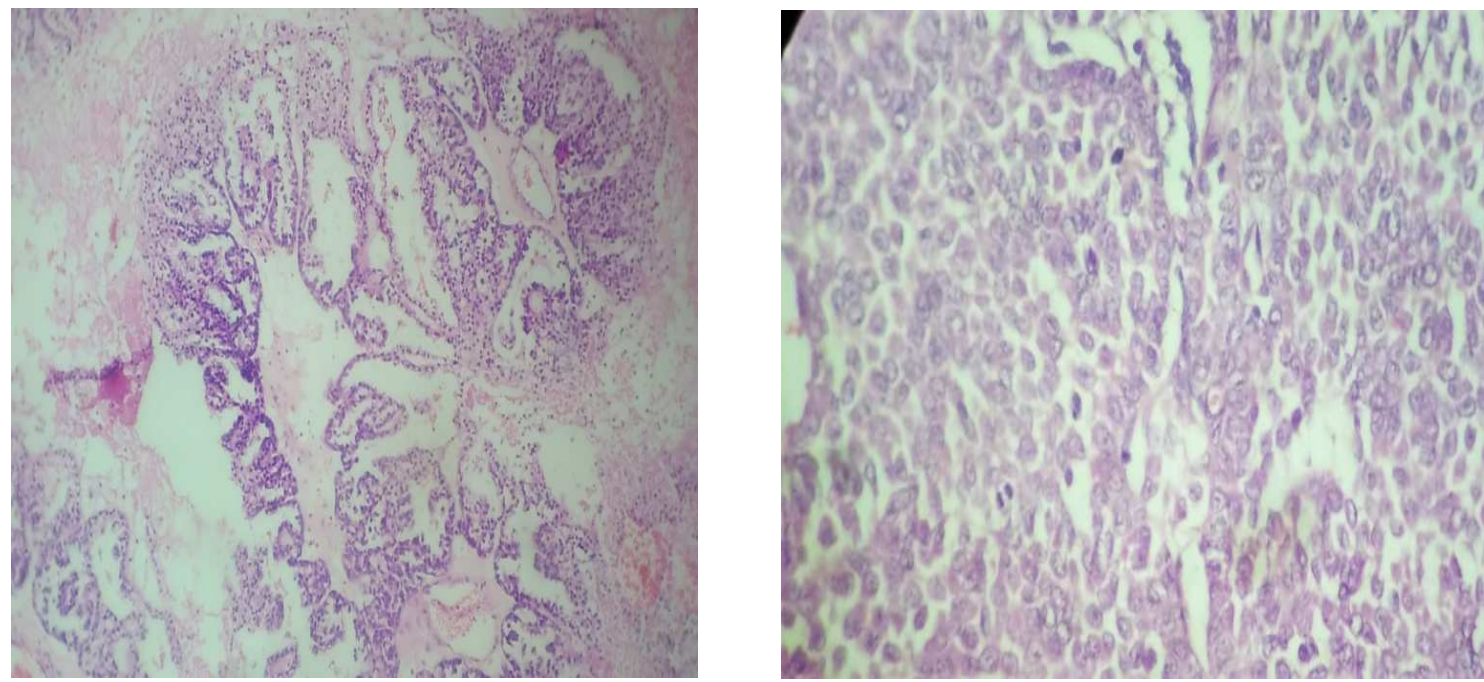

Figure-5: Clear Cell Carcinoma

(Tubulo-cystic and papillary pattern)

(10x, H \& E stain)
Figure-6: Granulosa Cell Tumour (Neoplastic cells arranged in sheets with prominent nuclear grooving imparting coffee bean appearance) (40x, H \& E stain)

\section{Discussion}

Ovarian cancer is second leading cause of mortality amongst all the cancers of female genital tracts. Due to similar clinical presentation, it is difficult to diagnose non-neoplastic and neoplastic cystic lesions of ovary although it is labelled as cystic lesion on ultrasonography and hence removed prophylactically in routine oophorectomies and hysterectomies [9].

Ovarian neoplastic cystic lesions may occur at any age, including infancy and childhood. Incidence rate however increase with age, with the greatest number of new cases being diagnosed between 4th and 5th decade.

The non-neoplastic cystic lesions like follicular and corpus luteum cysts are commonly encountered conditions. Zaman et al. had studied 498 cases in one year. The authors encountered $68.87 \%$ non-neoplastic lesions and $31.12 \%$ neoplastic lesions [10]. In our study 58\% lesions were non-neoplastic and $42 \%$ were neoplastic. Out of all the non-neoplastic cystic lesions $46.55 \%$ were follicular, $44.82 \%$ were corpus luteal and $8.63 \%$ were endometriotic cysts.

Maliheh et al. found serous cystadenoma (38\%) followed by mature cystic teratoma (30\%) \& mucinous cystadenoma (22\%) [11]. We have 39\% mature cystic teratoma, 28\% serous cystadenoma and 33\% mucinous cystadenoma in our study. Most common benign tumor in the studies done by Mondal et al, Iqbal et al. \& Yasmin et al. were serous cystadenoma ( $29.9 \%, 38.5 \%$ and $24 \%$ respectively ) followed by mature cystic teratoma $(15.9 \%, 30.8 \%$ and $18 \%$ respectively ) $[12,13,14]$.

In present study, 42 neoplastic cystic lesions were diagnosed. Most common were benign followed by, borderline and malignant. Based on histomorphological features, incidence of surface epithelial cystic tumours were commonest 26 (61.9\%) followed by germ cell tumours $14(33.3 \%) \&$ sex cord tumours $2(4.8 \%)$. None of the neoplastic lesion was metastatic in our study. In Gupta et al. study surface epithelial tumours were the commonest (48.8\%) followed by germ cell tumours (23.9\%), sex cord stromal tumors $(8.3 \%)$ and metastatic tumours (2.0\%) [15].

Gurung et al. had follicular cyst as $4^{\text {th }}$ commonly encountered lesion as compared to mature cystic teratoma and endometriotic cyst. Maharjan and Zaman et al. found corpus luteal cyst as commonest in their study, however the study done by Pudasaini et al. was comparable to other studies as they had serous cystadenoma commonest followed by mature cystic teratoma and hemorrhagic corpus luteal cyst $[16,17,18]$.

Laterality of ovarian neoplastic lesions in various studies in comparison with present study is illustrated in Table 4. Our study revealed that 94 out of 100 ovarian specimens were unilateral (94\%) and only (6\%) were bilateral. Our findings are in concordance with other studies [19,20,21,22]. 


\section{Original Research Article}

Table-4: Laterality of ovarian neoplastic lesions in various studies in comparison with present study.

\begin{tabular}{|c|c|c|}
\hline \multirow{2}{*}{ Authors } & \multicolumn{2}{|c|}{ Laterality } \\
\cline { 2 - 3 } & Unilateral & Bilateral \\
\hline Prabhakar et al & $90.9 \%$ & $9.1 \%$ \\
\hline Misra et al & $95.5 \%$ & $4.5 \%$ \\
\hline Couto F. et al & $91.2 \%$ & $8.8 \%$ \\
\hline Kar et al. & $73.13 \%$ & $26.87 \%$ \\
\hline Present Study & $94 \%$ & $6 \%$ \\
\hline
\end{tabular}

The percentage distribution of patients in various age groups in comparison with other studies is illustrated in Table 5 . The majority of our patients were in the age group $20-39$ years (54\% of patients) while those in the age group 40-59 years were the second largest group of patients ( $40 \%$ of patients). This is in concordance with the studies of Ramachandran et al (20-39 years $-53.0 \%$; $40-59$ years $-30 \%$ of patients) and Pilli et al (20-39 years $-58.0 \%$; $40-59$ years-30\% of patients) $[23,24]$.

Table-5: Percentage distribution of cases in various age groups in comparison with present study.

\begin{tabular}{|c|c|c|c|c|}
\hline \multirow{2}{*}{ Authors } & \multicolumn{4}{|c|}{ Age group in years } \\
\cline { 2 - 5 } & $\mathbf{0 - 1 9}$ & $\mathbf{2 0 - 3 9}$ & $\mathbf{4 0 - 5 9}$ & $\geq \mathbf{6 0}$ \\
\hline Ramchandran et al & $7.9 \%$ & $53 \%$ & $30 \%$ & $9.1 \%$ \\
\hline Pilli et al & $7 \%$ & $58 \%$ & $30 \%$ & $5 \%$ \\
\hline Kar et al & $7.4 \%$ & $41.7 \%$ & $46.2 \%$ & $4.4 \%$ \\
\hline Present Study & $4 \%$ & $54 \%$ & $40 \%$ & $2 \%$ \\
\hline
\end{tabular}

Ovarian cancers are known as "silent killers" as most of the primary ovarian tumours remain asymptomatic until the advanced stage. However, histomorphological study of tumour is still a gold standard method today to diagnose and classify them into neoplastic and non-neoplastic cystic lesions. These observations and results may provide valuable base line information regarding frequency and pattern of non neoplastic and neoplastic ovarian cystic lesions in urban settings like our Vadilal Sarabhai General Hospital, Ahmedabad, India.

\section{Conclusion}

All these histomorphological parameters along with advanced newer diagnostic modalities like immunohistochemistry can help early diagnosis, plan the line of treatment and have effect on prognostic significance.

Because of the geographic location, poverty and illiteracy, patients seek medical advice late in rural health facility. So, along with proper histomorphological study, awareness among public and doctors, education of people, passive surveillance, and community screening facility will also be helpful in early detection of the ovarian cystic lesions and tumours. This study shows the commonest benign and nonneoplasic cystic lesions of ovary. This study also shows wide histomorphologic spectrum of ovarian cystic lesions. This distinction is very much important clinically to further plan the management accordingly.

\section{What this study adds to existing knowledge?}

Our distribution of histomorphologic spectrum of ovarian cystic lesions is similar to most of the other studies worldwide as stated in discussion. However we had only few cases of malignant lesions as compared to others. Genetic profiling and Immunohistochemistry in prospective study may provide more details and elaborate the facts.

\section{Contribution by authors}

Study Conception and Design: Dr. Anand \& Dr. Dhaval, Acquisition of Data: Dr. Anand \& Dr. Dhaval, Analysis and Interpretation of Data: Dr. Ankur, Dr. Anand \& Dr. Dhaval, Drafting of Manuscript: Dr. Ankur, Dr. Anand, Critical Revision: Dr. Ankur, Dr. Anand.

Funding: Nil, Conflict of interest: None initiated Permission from IRB: Yes

\section{References}

1. Rosai J, Rosai and Ackerman's Surgical Pathology, Rosai,10 ${ }^{\text {th }}$ ed,Edinburg:MosbyElsevier;2011:1553-1554.

2. Warner BW, Kuhn JC, Bar LL. Conservative management of large ovarian cysts in children: The value of serial pelvic ultrasonography. Surgery 1992; 112: 749-55. 


\section{Original Research Article}

3. Choudry A , Bangash N, Malik A, Choudry H. Adolescent ovarian tumors: a clinicopathlogical review of 15 cases. J Ayub Med Coll Abbottabad. 2008 OctDec; 20 (4):18-21

4. Pudasaini S, Lakhey M, Hirachand S, et al. A study of ovarian cyst in a tertiary hospital of Kathmandu valley. Nepal Med Coll J. 2011 Mar;13(1):39-41.

5. Tortolero L, Mitchell FM, Rhodes HE. Epidemiology and screening of ovarian cancer. Obstet Gyanecol Clin North Am. 1994;21:63-75

6. Merino MJ, Jaffe G. Age contrast in ovarian pathology. Cancer. 1993 Jan 15;71(2 Suppl):537-44.

7. Malik IA. A prospective study of clinicopathological features of epithelial ovarian cancer in Pakistan. J Pak Med Assoc. 2002 Apr; 52 (4):155-8.

8. Bhattacharya M, Shinde SD, Purandare VN A clinicopathological analysis of 270 ovarian tumours. J Postgrad Med. 1980 Apr;26(2):103-7.

9. Rosai J, Rosai and Ackerman's Surgical Pathology, Rosai, $10^{\text {th }}$ ed, Edinburg: Mosby Elsevier; 2011:1557.

10. Zaman S, Majid S, Hussain M, et al. A retrospective study of ovarian tumours and tumour-like lesions. J Ayub Med Coll Abbottabad. 2010 Jan-Mar; 22 (1):104-8.

11. Maliheh A, et al. Surgical Histopathology of Benign Ovarian cysts, a multicentre study, Iranian journal of Pathology 2010; 5(3): 132-6.

12. Mondal SK, Et al. Histologic pattern, bilaterality and clinical evaluation of 957 ovarian neoplasms: A10year study in a tertiary hospital of eastern India. J Can Ras Ther2011; 7:433-7 (serial online) 2011 (cited 2014 Jan 3 ) ; 7:433-7.

13) Iqbal J. Et al, Pattern of ovarian Pathologies. Journal of Rawalpindi Medical College (JRMC) 2013; 17(1):113-5.
14. Yasmin S, Yasmin A, Asif M. Clinicohistological pattern of ovarian tumours in Peshawar region. J Ayub Med Coll Abbottabad. 2008 Oct-Dec;20(4):11-3.

15. Gupta N, Bisht D, Agarwal AK, Sharma VK. Retrospective and prospective study of ovarian tumours and tumour-like lesions. Indian $\mathbf{J}$ Pathol Microbiol. 2007 Jul;50(3):525-7.

16. Gurung P, Hirachand S, Pradhanang S. Histopathological study of ovarian cystic lesions in tertiary care hospital of Kathmandu, Nepal. Journal of Institute of Medicine. 2013; 35(3):44-7.

17. Maharjan S. Clinicomorphological study of ovarian lesions. Journal of Chitwan Medical College. 2013; 3 (6): 17-24.

18. Pudasaini S, Lakhey M, Hirachand S, et al. A study of ovarian cyst in a tertiary hospital of Kathmandu valley. Nepal Med Coll J. 2011 Mar;13(1):39-41.

19. Prabhakar BR, Maingi K. Ovarian tumours-prevalence in Punjab. Indian J Pathol Microbiol. 1989 Oct; 32(4):276-81.

20. Couto F, Nadkarni NS, Rebello MJ. Ovarian tumors in Goa. A clinicopathological study. J Obstet Gynecol of India. 1993;43(3):408-12.

21. Misra RK, Sharma SP, Gupta U, Gaur R, Misra SD. Pattern of ovarian neoplasms in eastern UP. J Obstet Gynecol. 1990;41(2):242-6.

22. Kar T, Kar A, Mohapatra PC. Intra-operative cytology of ovarian tumors. J Obstet Gynecol India. 2005; 55(4):345-9.

23. Ramachandran G, Harilal KR, Chinnamma K, Thangavelu H. Ovarian neoplasms -A study of 903 cases. J Obstet Gynecol India. 1972;22:309 -15.

24. Pilli GS, Suneeta KP, Dhaded AV, Yenni VV. Ovarian tumours: a study of 282 cases. J Indian Med Assoc. 2002 Jul;100(7):420, 423-4, 447.

\section{How to cite this article?}

Kanasagara A, Sarvaiya A, Sakariya D. Histomorphologic spectrum of ovarian cystic lesions at a tertiary care centre. Trop J Path Micro 2018;4(3):270-275.doi:10. 17511/jopm.2018.i3.06 